\title{
Makna Tradisi Butale Haji di Tigo Luhah Semurup Kabupaten Kerinci
}

\author{
Fatonah Nurdin*, Supian, Denny Defrianti \\ Prodi Ilmu Sejarah, Fakultas Keguruan dan Ilmu Kependidikan, Universitas Jambi \\ *Correspondence email: fatonah.nurdin@unja.ac.id
}

\begin{abstract}
Abstrak. Penelitian ini menggunakan metode kualitatif dengan tujuan untuk menghasilkan data kualitatif dengan pendekatan interaksi simbolik, melalui sejarah tradisi butale haji serta makna dan nilai dari tradisi butale haji dalam budaya masyarakat Tigo Luhah Semurup kabupaten Kerinci. Fokus penelitian ini adalah sejarah dan makna aktivitas tradisi butale haji di Tigo Luhah Semurup. Pemahaman tentang tradisi butale haji sebagai nilai interaksi simbolik dalam budaya masyarakat Tigo Luhah Semurup yang mengikat kekerabatan dan kebersamaan. Latar belakang dari penelitian ini adalah dimulai dari interaksi masyarakat Tigo Luhah Semurup yang telah terjadi interaksi selama bertahun-tahun dan berlangsung turun-temurun hingga saat ini. Pada saat berkumpul menikmati kebersamaan dan kegotongroyongan terjadi interaksi antara satu dan yang lainnya antar sesama warga dalam kegembiraan dan keharuan mengantar saudara mereka untuk berangkat ke tanah suci Mekkah. Hasil penelitian ini memperlihatkan bahwa masyarakat Tigo Luhah Semurup sangat menjaga tradisi butale haji ini. Aktivitas butale haji yang dilakukan dengan sadar, dengan motif dan tujuan untuk menjaga hubungan kekerabatan, kebersamaan, gotongroyong dan keikhlasan dalam melaksanakan aktivitas tradisi butale ini juga menjadi sarana komunikasi antar kerabat untuk saling mendukung dan mendoakan kepergian saudara melaksanakan ibadah haji dengan gembira tanpa meninggalkan beban dan rasa khawatir. Kesimpulannya, aktivitas tradisi butale haji sebagai nilai penguat dan perekat hubungan kekeluargaan, kebersamaan, gotong royong, keikhlasan dalam masyarakat Tigo Luhah Semurup kabupaten Kerinci.
\end{abstract}

Kata kunci: Tale; Butale Haji; Petale; tradisi; Kerinci.

Abstract. This study uses qualitative methods with the aim of producing qualitative data with symbolic interaction approach through the history of Butale Haji tradition and to know the meaning and value of it, in the culture of the people of Tigo Luhah Semurup, Kerinci regency. The focuses of this research were the history and the meaning of the Butale Haji traditional activities in Tigo Luhah Semurup. Understanding of the Butale Haji tradition as the symbolic interaction value in the culture of Tigo Luhah Semurup society which binds kinship and togetherness. The background of this research was starting from the interaction of the Tigo Luhah Semurup society which has been an interaction for years and has been passed down from generation to generation till present. At the time of gathering to enjoy togetherness and mutual cooperation, there was an interaction between one another among fellow citizens in joy and compassion to take their siblings to the holy land of Mecca. The results of this study indicated that the society of Tigo Luhah Semurup really maintain this Butale Haji tradition. Butale Haji tradition which was carried out consciously, with the motive and purpose of maintaining kinship, togetherness, mutual cooperation and sincerity in doing activities. Butale Haji was also as the means of communication between relatives to support each other and pray for the departure of siblings to do Hajj with happily without leave the burden and worry. In conclusion, Butale Haji traditional as the strengthening value and the adhesive friendship, togetherness, mutual cooperation, sincerity in the Tigo Luhah Semurup society in Kerinci regency.

Keywords: Tale; Butale Haji; Petale; tradition; Kerinci

\section{PENDAHULUAN}

Manusia dalam kesehariannya tidak bisa terlepas dengan kebudayaan, hal ini dikarenakan manusia merupakan sebagai pencipta serta yang menggunakan kebudayaan tersebut. Masyarakat dan kebudayaan adalah dua hal yang tidak sama akan tetapi memiliki kaitan yang sangatlah erat. Kebudayaan ada di muka bumi karena adanya manusia. Dengan kata lain, tidak akan ada masyarakat yang tidak memiliki kebudayaan dan kebalikannya tidak akan ada kebudayaan tanpa memiliki masyarakat pendukung. Kebudayaan ada karena adanya manusia yang menciptakannya. Oleh sebab itu, manusia hidup dikarenakan adanya keberadaan kebudayaan, dan sebaliknya kebudayaan itu sendiri akan terus ada dan berkembang ketika manusia akan selalu melestarikan kebudayaan itu sendiri dan bukan sebaliknya akan merusak kebudayaan itu sendiri.
Artinya, bahwa manusia dan kebudayaan seperti dua sisi mata uang yang tidak bisa dipisahkan. Hal tersebut, disebabkan didalam kehidupan manusia tidak akan mungkin tidak berhubungan atau berkaitan dengan namanya produk dari suatu kebudayaan.

Kebudayaan selalu dimiliki oleh setiap anggota masyarakat. Karena didalam kehidupan setiap masyarakat, kebudayaan merupakan sesuatu hal yang paling berpengaruh dalam kehidupan masyarakan. Hal tersebut, dikarenakan kebudayaan dapat dikatakan sebagai acuan ataupun pedoman dalam melakukan berbagai aktivitas kehidupan dalam masyarakat.

Berdasarkan penjelasan diatas, maka peneliti tertarik untuk mengkaji makna dari tradisi butale dalam kehidupan masyarakat Tigo Luhah Semurup Kabupaten Kerinci ini dikarenakan tradisi butale ini merupakan 
warisan budaya dari dahulu hingga saat ini tradisi butale masih dilakoni oleh masyarakat desa Pasar Semurup.

Tradisi butale merupakan satu bentuk tradisi yang telah dilakukan oleh masyarakat Kerinci tepatnya di Tigo Luhah Semurup sampai saat ini masih dilakukan tradisi tersebut oleh masyarakat setempat yakni tradisi tale naik haji. Tale naik haji ini merupakan salah satu dari tradisi bagi masyarakat sebelum melaksanakan ibadah haji pada masyarakat Kerinci, yang mana tradisi dari kebudayaan ini telah dilaksanakan oleh masyarakat setempat secara turun temurun hingga saat ini. Hal ini lah yang menjadi latar belakang penelitian tentang "Makna tradisi butale haji di Tigo Luhah Semurup Kabupaten Kerinci."

\section{METODE}

Penelitian ini merupakan metode peneltian kualitatif menggunakan pendekatan fenomenologis dan teori interaksi simblolik. Penelitian kualitatif merupakan penelitian yang melakukan analisis dan interpretasi teks dan hasil interview dengan tujuan untuk menemukan makna dari suatu fenomena.

Penelitian kualitatif adalah penelitian yang menekankan pada quality atau hal yang terpenting dari sifat suatu barang/jasa. Hal yang terpenting dari suatu barang atau jasa berupa kejadian atau fenomena adalah makna dibalik kejadian tersebut yang dapat dijadikan sebagai pelajaran berharga bagi suatu pengembangan konsep teori (Satori \& Komariah, 2009).

Suatu penelitian kualitatif dieksplorasi dan diperdalam dari suatu fenomena sosial atau suatu lingkungan sosial yang terdiri atas pelaku, kejadian, tempat dan waktu. Hal yang sama juga diungkapkan oleh Denzin \& Lincoln bahwa penelitian kualitatif merupakan penelitian yang menggunakan latar alamiah, dengan maksud menafsirkan fenomena yang terjadi dan dilakukan dengan jalan melibatkan berbagai metode yang ada. Hal yang senada juga dijelaskan oleh Berg (dalam Satori \& Komariah, 2009), ia menyatakan bahwa pendekatan kualitatif menunjukkan pada penelitian yang bersifat naturalistik, fenomenologis serta penelitian etnografi.

Hal yang sama juga diungkapkan oleh Saldana (dalam Sugiyono, 2019), ia menjelaskan bahwa penelitian kualitatif dapat dikatakan sebagai penyokong dari semua jenis metode pendekatan penelitian yang digunakan dalam mengkaji kehidupan sosial yang bersifat natural/alamiah. Dalam hal ini, penelitian yang dilakukan untuk mendapatkan informasi yang diperoleh kemudian selanjutnya dianalisis secara kualitatif (nonkualitatif). Informasi dapat berbentuk transkrip hasil dari dokumen, catatan lapangan, wawancara dan atau bahan-bahan yang bersifat visual seperti photo, video, bahan dari internet dan dokumen-dokumen lain tentang kehidupan manusia secara individual ataupun kelompok.

Dalam penelitian kualitatif yang menjadi instrument utamanya adalah peneliti sendiri, namun selanjutnya setelah fokus penelitian menjadi jelas, kemudian ada kemungkinan akan dikembangkan instrument penelitian sederhana, yang mana diharapkan dapat melengkapi data serta membandingkan dengan data yang telah diperoleh dengan cara observasi dan wawancara. Peneliti akan ke lapaangan sendiri, baik berupa grand tour question, tahap focused and selection, setelah itu melakukan pengumpulan data, dan selanjutnya melakukan analisis dan membuat kesimpulan (Sugiyono, 2007).

Selanjutnya cara pengumpulan data pada penelitian merupakan langkah yang paling utama dalam penelitian karena tujuan dari suatu penelitian adalah untuk memperolah data. Maka, pengumpulan data dapat menggunakan sumber primer dan sumber sekunder. Dengan demikian, ada beberapa cara pengumpulan data menurut Sugiyono, yakni "melalui observasi, wawancara, dokumentasi, triangulasi atau gabungan" (Sugiyono, 2007).

Teknik pengumpulan data melalui wawancara dapat dilakukan apabila peneliti menemukan permasalahan yang hendak diteliti, serta peneliti berkeinginan untuk mengetahui hal-hal yang berhubungan dengan informan lebih mendalam. Wawancara yang mendalam dilakukan dalam konteks observasi partisipasi. Dalam hal ini, dimana terutama dalam kehidupan informal peneliti terlibat secara intensif dengan setting penelitian (Satori \& Komariah, 2009).

Berdasarkan sifat dari penelitian kualitatif ini, maka informasi yang didapat tidak saja diperoleh dari manusia tetapi juga berupa peristiwa, situasi yang diobservasi dalam penelitian ini. Informan memberikan data primer yang berkaitan langsung. Pendekatan kualitatif dalam hal penerapan nya, hal ini disesuaikan dengan alasan bahwa adanya kemungkinan data yang didapat oleh peneliti di lapangan bisa berbentuk data yang dapat berupa fakta yang selanjutnya membutuhkan analisis yang lebih mendalam. Sehingga pada pendekatan kualitatif ini akan cenderung melihat pada pencapaian data yang bersifat lebih mendalam terutama dengan adanya keterlibatan peneliti sendiri di lapangan. Dalam penelitian kualitatif, seorang peneliti bukan saja sebagai seorang peneli akan tetapi seorang peneliti juga bisa menjadi instrument utama dalam mengumpulkan data yang dapat berhubungan atau sesuai dengan instrument atau objek penelitian yang ingin diteliti oleh seorang peneliti (Sugiyono, 2005)

Pada penelitian ini seperti yang telah dijelaskan diawal, tim penulis menggunakan metode kualitatif dalam pengumpulan data di lapangan, pendekatan dengan teori interaksionalisme simbolis dan fenomelogis dengan wawancara yang mendalam dan observasi partisipan pada masyarakat yang melakukan tradisi butale haji di Tigo Luhah Sumurup kabupaten Kerinci.

HASIL DAN PEMBAHASAN Sejarah Tridisi Butale Haji 
Menunaikan ibadah haji adalah merupakan suatu bentuk ritual tahunan yang dilaksanakan kaum muslimim. Haji merupakan ibadah yang wajib dijalani sekali seumur hidup bagi umat Islam yang mampu. Ibadah haji merupakan ibadah yang istimewa karena menggabungkan finansial serta fisik. Oleh karena itu, bukan saja mengeluarkan keringat secara fisik akan tetapi orang yang menunaikan ibadah haji juga mengorbankan harta bendanya. Umat Islam yang akan menunaikan ibadah haji harus pergi meninggalkan tanah airnya dengan mengalami berbagai rintangan dan menjalani kehidupannya.

Untuk mengantar perjalanan jamaah haji menuju tanah suci, di Kerinci terdapat tradisi yang dinamakan butale yang merupakan salah satu tradisi masyarakat Tigo Luhah Semurup yang telah berasimilasi dengan ajaran Islam, sehingga masih dipertahankan sampai sekarang ini. Tradisi butale dianggap sebagai tradisi yang mesti dilaksanakan. Tradisi butale haji adalah merupakan suatu tradisi yang menjadi salah satu bagian dari tradisi yang unik dalam proses perjalanan sebelum keberangkatan calon jama'ah haji dalam menunaikan ibadah hajinya. Tradisi ini telah berlangsung secara turun temurun. Ibadah haji mempunyai pengaruh yang begitu mendalam bagi masyarakat Tigo Luhah Semurup. Haji mampu menembus kultur pada masyarakat Tigo Luhah Semurup dengan ragam budayanya. Tale haji menjadi salah satunya tradisi masyarakat Kerinci khususnya pada masyarakat Tigo Luhah Semurup yang telah ada dan dilakukan dari sejak dulu sampai sekarang masih terus dilakukan tradisi ini.

Berawal dari lamanya perjalanan untuk melaksanakan ibadah haji. Maka masyarakat Kerinci yang akan melaksanakan ibadah haji harus bersungguhsungguh dalam mempersiapakan perjalanan ibadah mereka. Salah satunya adalah mempersipkan fisik dan materi. Menurut Nukman (42), "konon, untuk melaksanakan ibadah haji masyarakat Kerinci harus menempuh perjalan yang panjang, jalan kaki dari Kerinci menuju Kota Padang, dari Kota Padang lanjut lagi perjalanan menuju Malaka, dari Malaka baru ke Mekkah." Masih menurut Nukman, Hal tersebut ditempuh selama berbulan-bulan bahkan bertahun-tahun, tidak jarang mereka harus bekerja terlebih dahulu selama beberapa kurun waktu di Malaka untuk mengumpulkan finansial ke Tanah Suci Mekkah, saat itu perjalan ibadah haji belum seperti saat ini, dengan kemudahan melalui jalur udara. Mereka harus menaiki kapal selama berbulan-bulan di kapal, sehingga perjalan ibadah haji tersebut akan memakan waktu yang cukup lama, dan tidak bisa diprediksi apakah mereka akan kembali dengan selamat dalam waktu cepat dan berkumpul bersama keluarga di kampung halaman. Oleh karena itu untuk mengantarkan kepergian mereka maka diadakanlah tradisi melepas kepergian mereka dengan doa serperti nyanyian tale tersebut.
Munculnya tale itu sendiri sangatlah berkaitan dengan masuknya dan perkembangan Islam di tanah Kerinci. Lebih lanjut Nukman (42) menjelaskan, kata "tale" berasal dari kata "tahlil" yang dapat diartikan mentauhidkan tuhan (Allah). Yang mana adanya penambahan kata "hu ala" atau "alaahu ala" yang lazim disisipkan dalam sampiran isi pantun dalam tale tersebut, yang berasal dari kata "hu Allah" dan "Allahhu ta'ala yang dapat diartikan Dia Allah dan Tuhan yang maha tinggi. Hal ini dapat dikatakan bahwa tale haji sebagai bukti sebagai seni budaya yang merupakan sebagai alat bagi penyebaran agama Islam pada masyarakat Kerinci. Tradisi Tale dilaksanakan pada saat melepaskan anggota keluarga atau anggota masyarakat yang akan menjalankan ibadah haji. Tradisi tale ini biasanya dilakukan setiap malam. Tradisi ini merupakan bagian dari kegiatan sebagai pelepasan sebelum keberangkatan calon jamaah haji.

\section{Makna Tradisi Butale Haji}

Esensi seorang muslim yang baik adalah menyempurnakan din-nya (agama), salah satunya adalah menyempurnakan rukun Islam hingga rukun ke lima, yaitu melaksanakan ibadah haji. Ibadah haji merupakan puncak esensi bagi seorang muslim. Meskipun perintah Allah tersebut tidak mewajibkan secara mutlak, ada kata tambahan bagi yang mampu, mampu dalam hal ini baik secara materi mau pun inmateri. jika belum mampu cukup dengan niat akan melaksanakan ibadah haji tersebut. Namun demikin bisa melaksakan ibadah haji merupakan harapan dan doa hampir semua umat muslim di dunia. Begitu juga dengan umat muslim di desa Tigo Luhah Semurup yang tentu saja memiliki impian dan tekad untuk menyampurnakan pelaksanaan rukun Islam yang ke lima dengan berbagai cara dan tradisi akan dijalankan. Salah satu tradisi yang terus berlangsung dari generasi ke generasi adalah tradisi butale haji.

Nukman (42) menuturkan, Butale berasal dari kata "Tale" yang artinya adalah "nyanyian" dan "butale" memiliki pengertian konten atau kegiatan dari tale tersebut. Sedangkan Petale adalah orang-orang melakukan kegiatan tale tersebut. Butale haji merupakan kegiatan yang dilakukan oleh para petale dalam mengantar persiapan para jamaah Kerinci tuk melaksanakan ibadah haji. Butale merupakan tradisi yang sudah sejak lama didendangkan dengan memiliki nada khas yang dilakukan oleh masyarakat. Tale dapat diartikan sebagai nyanyian rakyat atau bernyanyi bersama yang berasal dari kata "tala" yang artinya ukuran bunyi. Butale merupakan nyanyian rakyat dan kesenian tradisi lisan yang telah dilakukan oleh masyarakat sejak dahulunya.

Bernyanyi atau biasa disebut dalam bahasa Kerinci dengan sebutan "butale". Kegiatan butale ini dilaksanakan oleh petale. Petale sebutan untuk orang yang membawakan lagu pada saat tale berlangsung. Petale dapat dilakukan oleh kaum pria maupun kaum 
wanita. Pada saat butale bisa dilakukan sendiri atau banyak orang.

Lantunan tale yang kita dengarkan itu menandakan bahwa ada anggota keluarga atau anggota masyarakat yang akan bertolak ke tanah suci untuk beribadah. Pada saat sebelum melaksanakan ibadah haji, ada suatu tradisi yang unik dilakukan oleh masyarakat yakni disebut dengan tale haji. Yang mana orang yang akan melaksanakan ibadah haji terlebih dahulu ditalekan. Tale disenandungkan dengan menggunakan bahasa daerah.

Lantunan tale berbentuk syair yang berupa pantun-pantun yang memiliki makna atau pesan. Syair dalam butale mengungkapkan perasaan sedih, kerinduaan serta gembira. Tradisi butale ini menggunakan bahasa daerah Kerinci. Dapat kita lihat pada kondisi saat sebelum keberangkatan calon haji menunaikan ibadah haji, maka bisa kita lihat disetiap desa kita akan mendengarkan lantunan tale yang dinyanyikan oleh petale yang itu merupakan pertanda bahwa ada warga yang akan menunaikan ibadah haji. Untuk jamaah yang akan menunaikan ibadah haji terlebih dahulu di talekan dari rumah ke rumah apalagi yang ada hubungannya dengan keluarga.

Butale yang dilakukan oleh masyarakat menjadi suatu kegiatan rutin setiap tahunnya yang menunjukkan dari bentuk adanya rasa kebersamaan akan terlihat diantara anggota masyarakat ketika pada saat adanya anggota masyarakat atau anggota keluarga yang akan menunaikan ibadah haji. Tempat dilaksanakannya butale ini dilaksanakan secara bergiliran di rumah orang yang akan melaksanakan ibadah haji tersebut. Isi dari lantunan tale ini berupa doa-doa serta nasehat dari petale bagi orang yang akan menunaikan ibadah haji.

Deskripsi uraian diatas, terlihat bahwa tradisi butale ini menggambarkan adanya bentuk kebersamaan antara masyarakat. Tidak hanya berfungsi sebagai hiburan akan tetapi juga berfungsi sebagai ritual yang telah menjadi tradisi setiap tahunnya yang merupakan sebagai prosesi menjelang keberangkatan calon jama'ah haji sebelum menunaikan ibadah haji. Syair atau lantunan yang dibawakan oleh petale yang isinya berupa doa-doa dan harapan bagi calon jamah haji yang akan menunaikan ibadah haji. Dari sinilah mulainya butale itu. Pelaksanaan tradisi butale ini akan dilakukan secara bergiliran oleh kelompok petale secara bergiliran ke rumah sanak saudara maupun anggota masyarakat yang akan berangkat dalam menunaikan ibadah haji. Begitulah seterusnya sampai menjelang keberangkatan. Pada hari keberangkatan, masyarakat akan tumpah ruah memenuhi masjid (upacara pelepasan secara resmi) dan kemudian mengantar dengan berjalan kaki.

Tale yang dilantukan ini terdengan seperti syair lafaz al-berzanzi dalam bahasa Arab, namun bukan bahasa Arab, tetapi bahasa daerah Kerinci dinyanyikan "ditale"kan seperti bahasa Arab. Isi makna dari tale ini sangatlah mendalam. Orang-orang yang mendengarkan para petale malakukan butale akan terbawa dalam suasanan kesaduannya baik itu para jamaah maupun masyarakat yang mengantarkan. Seperti yang diungkapkan oleh jamaah haji ibu Aisyah (59), "ada rasa gembira dan sedih setelah dibutale, gembira karena kita akan berangkat ke Tanah suci, sedih karena kita akan meninggalkan keluarga dan kampung halaman sementara." dan hal senada juga diungkapkan oleh jamaah pak Fahmi Adam (65), "ada perasaan terharu dan gembira, terharu seolah-olah kita sudah sampai ke Mekkah, dan gembira karena sanak keluarga semua berkumpul bersilaturahmi untuk mengantar dan mengirii kita dengan doa." mereka mengungkapkan ada rasa haru dan gembira bercampur menjadi satu tak kala mendengarkan tale yang dilantukan oleh para petale. ada rasa haru karena isi makna pesan-pesan yang diungkapkan dalam bait-bait tale tersebut. Tale yang dilantunkan oleh para petale mensugesti orang-orang yang akan berangkat melaksanakan ibadah haji agar tidak ragu dan terus berserah diri pada Allah SWT semata.

Kegiatan tradisi butale ini biasa belangsung dari mulai 1 bulan sebelum keberangkatan menuju Tanah suci hingga 1 hari sebelum meninggalkan Kerinci menuju asrama haji di Jambi. Butale dilakukan setelah selesai shalat Isya hingga samapai tengah malam bahkan ada hingga fajar sebelum adzan shalat subuh dikumandangkan.

Tradisi butale ini merupakan suatu budaya yang telah ada dari sejak dahulu hingga saat ini masih tetap dilestarikan, hal ini telah menjadi tradisi yang yang melekat pada masyarakat Kerinci dan telah menjadi suatu identitas budaya bagi masyarakat setempat yang setiap tahunnya dilaksanakan tradisi butale ini yang mana isinya berupa kesedihan, harapan dan kegembiraan, hal tersebut merupakan simbol dalam bentuk doa dan harapan sebagai proses pelepasan anggota masyarakat ataupun anggota keluarga mereka sebagai makna dari bentuk rasa bersyukur atas keberangkatan anggota masyarakat atau anggota keluarga yang akan menunaikan ibadah haji dengan harapan supaya tidak akan mendapat halangan atau kendala apapun pada saat berangkat maupun kembali ke tanah air dalam menjalankan ibadah haji dalam kondisi sehat wal'afiat dan menjadi haji mabrur.
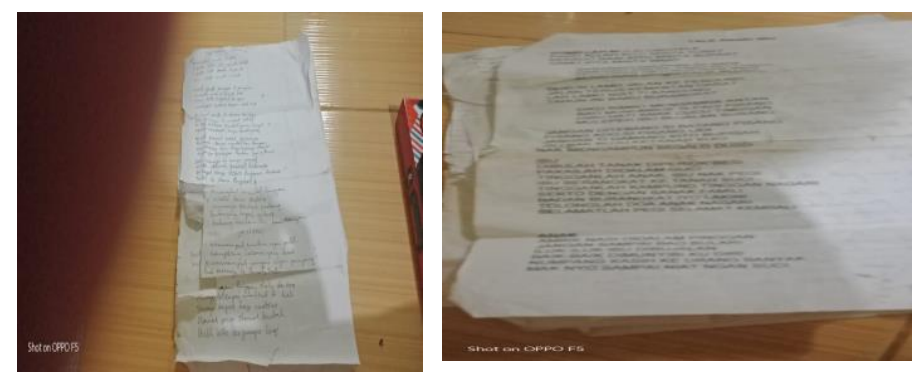

Keterangan: teks tale yang dilantunkan oleh para petale. Dok. Pribadi. 
Bu tale kito sahi inih

Malepeh dusanak pegi ke Mekah

Apu hikmah negeri Mekah

Muku hati semabuk ini

Terjemahan:

Butale kita hari ini

Melepas saudara pegi ke Mekah

Apa hikmah negeri Mekah

Hingga hati sesedih ini

Ambek tali tebang durian

Durian ditebang nyu rebah

Kami butale hati kami riang

Melepeh jama'ah pegi ke Mekah

Terjemahan:

Ambil tali tebang pohon durian

Pohon durian ditebang sampai rebah

Kami butale hati kami riang

Melepas jama'ah pergi ke Mekah

Burung puntung terbang dulu

Tibo di ulu manite nite

Sanak baruntung berangkat dulu

Sanak dengan tinggan mencari pike

Terjemahan:

Burung bangau terbang duluan

Sampai dihulu meniti niti

Saudara beruntung berangkat dahuluan

Saudara yang ditingggal berpikir untuk bisa kesana juga

\section{Berlayar babilok-bilok}

Ayah bajalan hati idak ilok

Anak tinggan hati idak tenag

Terjemahan:

Berlayar berbelok-belok

Singgah berhenti di air yang tenang

Ayah berangkat hati menjadi cemas

Anak yang ditinggal membuat hati tidak tenang

Ilok ragi batk Semarang

Kain panjang ayam den lapeh

Jemaah haji nak bejalan

Samu-samu kito melepeh

Terjemahan:

Bagus motif batik semarang

Kain panjang ayam den lepeh

Jama'ah haji hendak berangkat

Sama-sama kita melepaskan keberangkatannya

Pecah geleh ditimpu lemari

Pecah piring dipecah lagi
Inih pesan kami butale

Sampai ka salam ka makam nabi

Terjemahan:

Pecah gelas ditimpa lemari

Pecah piring dipecahkan lagi

Ini pesan kami butale

Sampaikan slam ke makam Nabi

Apu tinggi kayu di jambi

Tinggi jugokayu di tungkal

Apu ibo kayo dengan pegi

Ibo jugo kami dengan tingggan

Terjemahan:

Seberapa tinggi kayu di jambi

Tinggilah juga kayu di Tungkal

Seberapa sedih saudara yang pergi berangkat

Lebih sedih kami yang ditinggal

Hu Allah batu ni Allah he yaho batu digumbak hu Allah

Hu Allah bu taletakAllah he yaho luwa mangkuto hu Allah

Hu Allah tujuh musim Allah he yaho di lamun umbak hu Allah

Hu Allah maksud atu Allah he yaho ku Mekah jugo

Terjemahan:

Batu Haji Batu Bergombak

Batu Terletak di luar Mahkota

Tujuh musim dilamun ombak

Maksud hati ke Mekkah jua

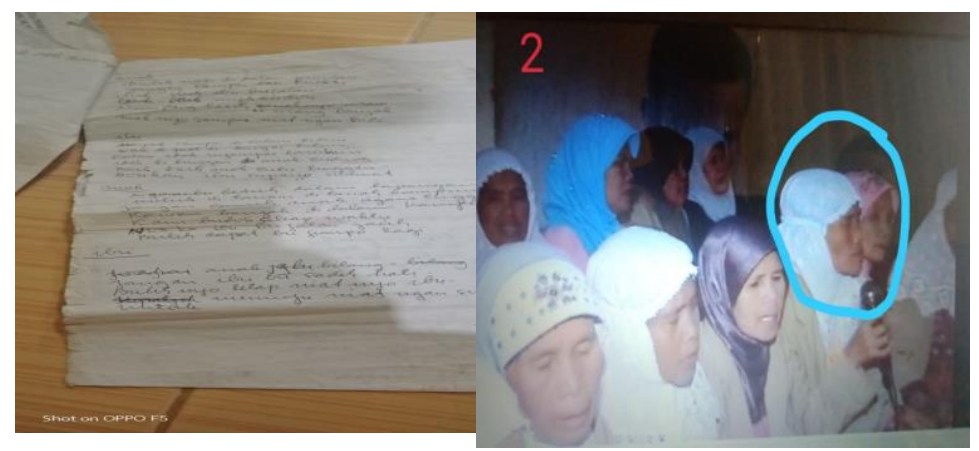

Keterangan: catatan teks tale yang dilantukankan para petale dalam tradisi butale. Dok.pribadi.

Begitulah bunyi sepenggalan syair yang disenandungkan petale bagi calon jama'ah haji yang hendak berangkat ke tanah suci untuk menunaikan ibadah haji. Menurut Eli Marzuki (52), Butale dilaksanakan Karena dulunya warga Kerinci yg ingin berangkat haji menggunakan kapal yang ada di Padang mereka harus melewati Jambi kemudian ke Padang baru lah Jamaah haji berangkat haji menggunakan kapal yang biasanya memakan waktu berubulan-bulan untuk sampai kesana. Biasanya dulu Jamaah haji yang berangkat untuk 
melaksakan Ibadah Haji di Mekkah dan Madinah Kadang sebagian Kelompok ada beberapa dari mereka yang tidak Pulang dari Ibadah haji Karena Meninggal dunia, Butale diadakan untuk kelurga jamaah haji, lantunan-lantunanan doa dalam syair tale diharapkan dapat memberikan semangat, ketabahan dan kesabaran untuk keluarga yang ditinggalkan, dan bagi jamaah Haji yang akan berangkan diberi semangat dan doa agar diberikan kekuatan dan keselamatan ketika hendak melaksanakan ibadah haji. Lirik dan bahasa tale yang dibawa kan di Kabupaten Kerinci disetiap daerahnya berbeda-beda sesuai logat /dialek daerah masing-masing namun makna dan tujuannya sama.

Dengan demikian, tradisi butale ini sangatlah erat kaitannya dengan teori interaksi simbolik. Karakteristik dasar dari teori interaksionisme simbolik ini adalah suatu hubungan yang terjadi antar manusia dalam masyarakat secara alami, begitu pun hubungan masyarakat dengan individu. Interaksi yang terjadi antar individu tersebut berkembang melalui simbol-simbol yang mereka ciptakan. Rangkaian peristiwa yang terjadi pada beberapa individu dalam masyarakat merupakan realitas sosial. Interaksi yang dilakukan antar individu tersebut berlangsung secara sadar. Interaksionisme simbolik juga berhubungan dengan gerak tubuh, antara lain; suara atau vokal, gerakan fisik, ekspresi tubuh, yang semuanya itu mempunyai makna yang disebut dengan simbol (Wirawan, 2012). Oleh sebab itu, butale merupakan suatu simbol yang berbentuk syair yang berisi doa-doa serta nasehat bagi anggota masyarakat yang akan menunaikan ibadah haji.

Tradisi masyarkat Tigo Luhah Semurup di Kerinci yang telah terjadi antar manusia secara alami dari hal ini mencerminkan karakteristik dari teori interaksi simbolik antar individu telah terjalin dengan baik. Menciptakan keterikatan dan hubungan yang harmonis antar sesama masyarakat.

\section{Nilai Tradisi Butale Haji}

Nilai merupakan suatu cerminan dari apa yang dikehendaki, yang layak serta yang berharga dan yang mempengaruhi dari tingkah laku seseorang. Dengan kata lain, bahwa nilai-nilai merupakan suatu pendukungpendukung dari suatu kebudayaan yang mendefiniskan apa yang dihendaki dan tidak dihendaki, apa yang baik dan tidak baik, apa yang indah dan jelek. Oleh sebab itu, nilai merupakan sebuah evaluasi atau sebagai pertimbangan tentang apa yang boleh dan tidak boleh menurut kebudayaan tertentu. Prinsip-prinsip ini tercermin di dalam setiap aspek kehidupan manusia. Dengan demikian, "nilai-nilai yang kita ketahui tersebut mengajarkan tentang seperti apa cara bertingkah laku yang sesuai dengan adat istadat dan budaya, tentang tujuan hidup yang dianggap layak oleh masyarakat dan tentang cara berelasi dengan sesama manusia." (SVD, 2016).
Butale merupakan sebagai bagian dari proses pelepasan anggota masyarakat atau anggota keluarga yang akan melaksanakan ibadah haji. Butale merupakan sebuah lantunan yang berisi doa-doa atau harapan kepada anggota masyarakat atau anggota keluarga yang akan melaksanakan ibadah haji. Dalam tradisi butale ini adanya terkandung suatu nilai-nilai yang terdapat dalam tradisi butale ini yakni nilai keagamaan, nilai kekeluargaan, nilai kebersamaan.

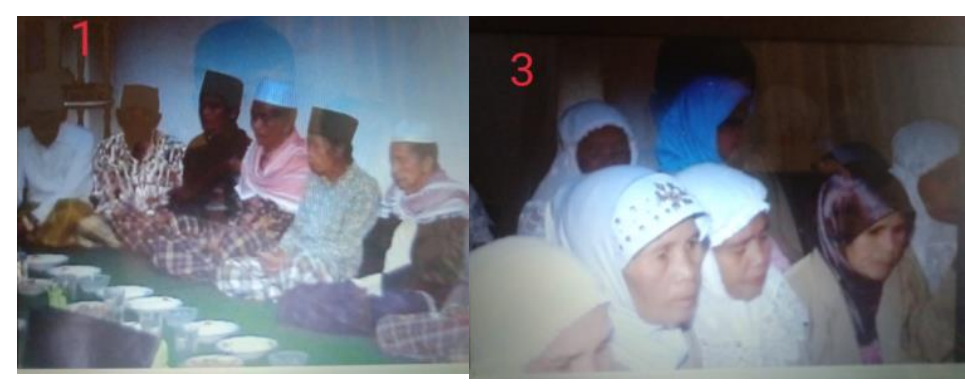

Keterangan: kegiatan butale dilaksanakan sebelum menjalankan ibadah haji. Dok. Pribadi.

Menurut Murgiyanto (dalam Sanjaya, 2019), ia mengemukakan bahwa bentuk dari kesenian dapat dilihat menjadi dua bentuk, yakni isi dan bentuk luarnya. Yang mana isi berkaitan dengan tema atau cerita dalam pertunjukan itu sendiri. Kemudian, yang kedua adalah bentuk dalam kesenian yang merupakan sebagai wadah untuk menuangkan isi yang disampaikan oleh seorang seniman.

Dengan demikian, jika dihubungkan dengan pertunjukan kesenian tale haji termasuk dalam kesenian tradisi karena sudah dilaksanakan sejak dahulu sampai sekarang. Dari bentuk dan isi, tale haji menjadi sebuah kesenian yang memiliki cerita dan pesan-pesan di dalamnya. Kesenian tradisi juga tidak terlepas dari sebuah kebudayaan serta kebudayaan terbentuk berdasarkan dukungan serta diteruskan oleh anggota dari suatu masyarakat. Oleh sebab itu, tradisi itu sendiri tidak terlepas dari suatu kebiasaan pada suatu masyarakat secara turun-temurun dari satu generasi ke generasi berikutnya, baik dalam bentuk tingkah laku maupun kesenian yang ada dalam suatu masyarakat itu sendiri.

Jika dilihat dari interaksi simbolik, maka akan terlihat beberapa nilai-nilai yang mengikat dalam tradisi butale tersebut, diantaranya adalah nilai kebersamaan, kekeluargaan, kekompakan, saling mengayomi, gotong royong dan keikhlasan.

\section{SIMPULAN}

Butale merupakan seni tradisi yang dilakukan oleh masyarakat Tigo Luhah Semurup di Kerinci. Senandung yang dilantunkan tanpa menggunakan alat musik, hanya mengandalkan suara yang dilantunkan sesuai dengan irama khas Kerinci secara bersama-sama. Senandung tale haji menggunakan bahasa daerah Kerinci yang mana setiap desanya memiliki irama dan cengkok yang berbeda satu sama lainnya dalam melantunkan syair tale 
sesuai dengan tradisi yang diwariskan oleh pendahulu mereka. Alunan suara yang memilukan hati bagi para jama'ah haji yang hendak meninggalkan kampung halaman dan sanak keluarganya.

Butale haji merupakan sebagai media yang efektif untuk mengungkapkan perasaan senang, dan sedih yang dapat disalurkan melalui seni dalam bentuk lantunan syair tale haji. Melalui tale ini, semua perasaan dan harapan diungkapkan terhadap calon jama'ah haji. Hal ini, dikarenakan pada waktu masih menggunakan kapal laut, masyarakat mengetahui betapa beratnya untuk melakukan perjalanan dalam menunaikan ibadah haji dengan kondisi ganasnya ombak laut. Oleh sebab itu, isi pesan yang mengandung doa dan harapan untuk tetap waspada agar selamat dalam ancaman bahaya ini mendominasi dalam isi tale haji. Tidak lupa pula disampaikan harapan agar tidak terlena di Mekkah Almukarramah, sehingga lupa pulang ke kampung halaman. Hal ini lah yang menjadi sejarah awal dilakukannya prosesi tale haji bersamaan dengan melaksanakan ibadah haji.

Pelepasan jama'ah haji pada masyarakat Kerinci menjadi peristiwa penting setiap tahunnya, selain menjadi sarana bagi petale untuk menunjukkan kemampuan dalam betale juga menjadi sarana untuk memperkuat ikatan sosial dalam masyarakat.

\section{DAFTAR PUSTAKA}

Sanjaya, Ficha Irwan \& Budiwirman. (2019)." Bentuk Dan Fungsi Tale Haji Dalam Acara Pelepasan Jamaah Haji Di Desa Pondok Agung Kecamatan Pondok Tinggi Kota Sungai Penuh”. J education (online), Vol.5, No.2

Satori, Djam'an \& Komariah, Aan. Metodologi Penelitian Kualitatif. 2009. Bandung: Alfabeta.

Sugiyono. (2019). Metode Penelitian Pendidikan (Kuantitatif, Kualitatif, Kombinasi, $R \& D$, Dan Penelitian Pendidikan). Alpabeta: Bandung. (2007). Metode Penelitian Pendidikan: Pendekatan Kuantitatif, Kualitatif, dan $R \& D$. Bandung: Alfabeta.

(2005). Memahami Penelitian. Bandung:Alfabeta.

SVD, Bernard Raho. (2016). Sosiologi. Flores: Ledalero. Wirawan, I.B. (2012). Teori-Teori Sosial Dalam Tiga Paradigma: Fakta Sosial, Definisi Sosial \& Perilaku Sosial. Jakarta: Kencana. 